University of Nebraska - Lincoln

DigitalCommons@University of Nebraska - Lincoln

Faculty Papers and Publications in Animal

Science

Animal Science Department

2011

\title{
Nutrient variability for distillers grains plus solubles and dry matter determination of ethanol by-products
}

C. D. Buckner

University of Nebraska-Lincoln

M. F. Wilken

University of Nebraska-Lincoln

J. R. Benton

University of Nebraska-Lincoln

S. J. Vanness

University of Nebraska-Lincoln

V. R. Bremer

University of Nebraska-Lincoln

See next page for additional authors

Follow this and additional works at: https://digitalcommons.unl.edu/animalscifacpub

Part of the Animal Sciences Commons

Buckner, C. D.; Wilken, M. F.; Benton, J. R.; Vanness, S. J.; Bremer, V. R.; Klopfenstein, T. J.; Kononoff, P. J.; and Erickson, G. E., "Nutrient variability for distillers grains plus solubles and dry matter determination of ethanol by-products" (2011). Faculty Papers and Publications in Animal Science. 759.

https://digitalcommons.unl.edu/animalscifacpub/759

This Article is brought to you for free and open access by the Animal Science Department at DigitalCommons@University of Nebraska - Lincoln. It has been accepted for inclusion in Faculty Papers and Publications in Animal Science by an authorized administrator of DigitalCommons@University of Nebraska - Lincoln. 


\section{Authors}

C. D. Buckner, M. F. Wilken, J. R. Benton, S. J. Vanness, V. R. Bremer, T. J. Klopfenstein, P. J. Kononoff, and G. E. Erickson 


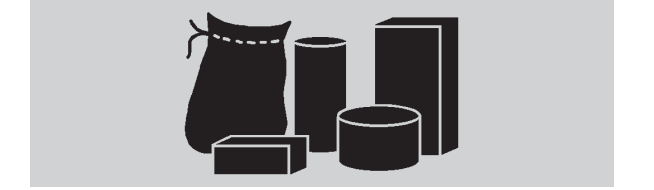 \\ Nutis grains plus solubles and dry matter determination of ethanol by-products ${ }^{1}$
}

\author{
C. D. Buckner, M. F. Wilken, J. R. Benton, PAS, S. J. Vanness, V. R. Bremer, T. J. \\ Klopfenstein, P. J. Kononoff, and G. E. Erickson, ${ }^{2}$ PAS \\ Department of Animal Science, University of Nebraska, Lincoln 68583-0908
}

\begin{abstract}
Three experiments were conducted to evaluate nutrient content and DM determination methods of dry milling byproducts. In Exp. 1, nutrient composition was determined for wet distillers grains plus solubles (WDGS) and modified distillers grains plus solubles (MDGS) from 6 ethanol plants with 10 samples collected per day, across $5 \mathrm{~d}$, and sampling was repeated over 4 separate months. Mean composition was 31.0\% CP, $11.9 \%$ fat, $0.84 \% P$, and $0.77 \% S$ (DM basis). Coefficients of variation for DM content were greater for some plants than others, and variation occurred within and across days. Variability was small for CP and $P$, whereas fat differed among ethanol plants. Large variation in means and $C V$ were observed for $S$ in period 1, but variation subsequently decreased. Coefficients of variation for $S$ were similar for samples collected within the same day and across days. In Exp. 2, samples of WDGS, MDGS, Dakota Bran Cake, and

\footnotetext{
${ }^{1}$ A contribution of the University of Nebraska Agricultural Research Division, supported in part by funds provided through the Hatch

${ }^{2}$ Corresponding author: geericks@unlnotes. unl.edu
} Act.
\end{abstract}

distillers solubles were used to determine DM content by drying samples at $105^{\circ} \mathrm{C}$ for 3, 8, and $24 \mathrm{~h}$ and $60^{\circ} \mathrm{C}$ for 24 and 48 h, vacuum oven drying, toluene distillation, and Karl Fischer titration. Compared with toluene distillation, drying at $105^{\circ} \mathrm{C}$ resulted in less $D M(P \leq$ 0.10) and vacuum drying and Karl Fischer titration resulted in greater DM ( $P$ $<0.01)$. In Exp. 3, additional WDGS, $M D G S$, and wet grains with no solubles were used to determine DM with oven drying at $60^{\circ} \mathrm{C}$ for $48 \mathrm{~h}$, oven drying at $105^{\circ} \mathrm{C}$ for $3 \mathrm{~h}$, or toluene distillation. Drying at $60^{\circ} \mathrm{C}$ for $48 \mathrm{~h}$ was similar to toluene distillation $(P \geq 0.60)$.

Key words: distillers grains, dry matter, laboratory method, nutrient composition, variation

\section{INTRODUCTION}

Although wet distillers grains plus solubles (WDGS) has become a common feedstuff in the livestock industry, there is concern about its nutrient composition and consistency (Babcock et al., 2008). Three nutrients commonly measured in WDGS are DM, fat, and S. Price paid for WDGS on a DM basis may be problematic if the DM content is less than expected or is incorrectly determined. If large amounts of high-fat WDGS are fed, then cattle intakes may decrease if dietary fat is greater than $8 \% \mathrm{DM}$ (Vander Pol et al., 2009). The NRC (1996) suggested the maximum tolerable $\mathrm{S}$ level was $0.40 \%$ for potential occurrence of polioencephalomalacia, thus making $\mathrm{S}$ in WDGS important if it is high or variable. Little research has been reported on nutrient variability with WDGS.

Methods to determine the DM of feeds are widely used in the agriculture industry. Given the variation in moisture, understanding these methods is of particular importance when considering wet ethanol by-products (50 to $70 \%$ moisture). Dry matter content of feeds is typically defined as the material remaining after heating the sample in an oven for a fixed period of time, with the calculated loss of weight assumed to be water. This method is used most commonly because it is rapid and inexpensive. However, Mo and Tjornhom (1978) determined volatile organic substances are also lost and additional side reactions may occur for wet, fermented forages during the oven-drying process. Toluene distillation offers an alternative method to determine 
DM content of feed through direct but separate removal of moisture (Brahmakshatriya and Donker, 1971). However, no published research exists for comparing DM methods in wet by-products. Our objectives were to determine nutrient composition plus variability for WDGS from several ethanol plants across many days and to compare drying methods to toluene distillation for determining DM of wet by-products.

\section{MATERIALS AND METHODS}

\section{Experiment 1}

Six ethanol plants in Nebraska agreed to sample distillers grains plus solubles. Four plants produced WDGS and 2 plants produced modified distillers grains plus solubles (MDGS), but the samples will be generally referred to as DGS to maintain confidentiality. A collected sample represented a semitruck load of DGS a cattle producer would receive. Samples were collected from 4 to 5 locations in the DGS pile to be loaded on a semitruck or from the loader that filled the truck. These samples were combined and mixed thoroughly, and a 250- to 500-g subsample was collected and placed into a plastic, air-tight bag and frozen. Ten samples were taken across a day for 5 consecutive days, with 50 total samples during the week. This was repeated over 4 sampling months (periods) throughout a year, totaling 200 samples per ethanol plant and 1,200 samples in the data set. Samples were shipped frozen overnight following the sampling period to the University of Nebraska-Lincoln ruminant nutrition laboratory for analysis.

Analyses for DM, CP, fat, P, and S content were conducted in duplicate. If the $\mathrm{CV}$ was greater than $5 \%$, then the analysis was repeated and the new results were used. Based on results from Exp. 1 and 2, DM analysis was conducted using a $60^{\circ} \mathrm{C}$ oven for 48 $\mathrm{h}$ because this method is statistically similar to toluene distillation. After drying, samples were ground through a 1-mm screen (Wiley Mill, Thomas
Scientific, Swedesboro, NJ) before nutrient analysis. Crude protein was calculated from percent nitrogen using a LECO nitrogen analyzer (LECO Corp., St. Joseph, MI; AOAC, 1999; method 990.03). Phosphorus and S were determined by wet ashing with nitric and perchloric acids and analyzed colorimetrically (AOAC, 1999; methods 968.08, 965.17; Tinsdale et al., 1985). Fat was determined by extraction with petroleum ether under pressure in filter bags (AOCS, 1998; method Am 5-04). Fat, P, and S analyses were performed at a commercial laboratory (Ward Laboratories Inc., Kearney, NE).

Data were summarized by day, ethanol plant, and sampling period to compare mean nutrient values. Coefficients of variation were calculated to evaluate variability within day, across day, and within plants. A CV was calculated each day (10 samples/d) within each ethanol plant and sampling period. These $5 \mathrm{CV}$ per ethanol plant and period were then averaged, and this CV value will be expressed as "within-day variation." Average nutrient content was calculated per day. These daily averages $(5 \mathrm{~d})$ within each period and ethanol plant were used to calculate a $\mathrm{CV}$, which will be expressed as "across-day variation." Statistical analysis on the within-day variation $\mathrm{CV}$ within period for each nutrient was conducted using the Proc Mixed procedure of SAS (Version 8.02, SAS Inst. Inc., Cary, NC), which used the within-day CV from each day as the experimental unit. This procedure was used to evaluate average ethanol plant nutrient composition by using average daily nutrient composition as the experimental unit. Probabilities less than or equal to 0.05 were considered significant.

\section{Experiment 2}

Four different types of high-moisture, by-product feeds were used to evaluate drying methods for determining DM content. These feed samples included WDGS (31-35\% DM; Abengoa Bioenergy, York, NE), MDGS (42-48\% DM; Husker Ag,
Plainview, NE), Dakota Bran Cake (Dbran, 50-54\% DM; POET Nutrition, Sioux Falls, SD), and distillers solubles (DS, 25-35\% DM; Abengoa Bioenergy). Random grab samples were obtained from the piles (representing one semitruck load) of wet byproducts that were being fed to cattle at the University of Nebraska-Lincoln Agricultural Research and Development Center research feedlot near Mead, Nebraska. These samples were mixed together (totaling $2.5 \mathrm{~kg}$ ) and subsampled for each analysis of DM.

Methods for determining DM included drying samples in a $60^{\circ} \mathrm{C}$ forced air oven for 24 or $48 \mathrm{~h}$, drying samples in a $105^{\circ} \mathrm{C}$ forced air oven for 3,8 , or $24 \mathrm{~h}$, using a vacuum oven, toluene distillation, and Karl Fischer titration. The $105^{\circ} \mathrm{C}$ and $60^{\circ} \mathrm{C}$ oven methods were conducted by weighing $5 \mathrm{~g}$ as-is sample into dry aluminum pans (8 replications). Weights were recorded on the same samples at 3 , 8 , and $24 \mathrm{~h}$ for the $105^{\circ} \mathrm{C}$ oven and at 24 and $48 \mathrm{~h}$ for a different set of samples in the $60^{\circ} \mathrm{C}$ oven. A vacuum oven analysis (AOAC, 1999; method 934.01) was conducted on each sample type (3 replicates). Samples were weighed ( $5 \mathrm{~g}$ as-is) into preweighed moisture tins and placed on a vacuum oven tray. Trays were placed in a $70^{\circ} \mathrm{C}$ vacuum oven, the door was sealed, and the vacuum was applied at $50 \mathrm{mmHg}$. After $4 \mathrm{~h}$, the vacuum was turned off, and the tins were removed from the tray, allowed to cool in a dessicator, and then weighed. In addition, a Karl Fischer titration (AOAC, 1999; method 2001.12; Thiex and Van Erem, 2002) was conducted in duplicate on all samples. Toluene distillation (AOAC, 1999; method 925.04) was conducted in duplicate on every sample. A 25-g as-is sample was weighed into a $250-\mathrm{mL}$ Pyrex roundbottom flask, and toluene was added to cover the sample. Toluene was rinsed down the sides of the condenser into the collection trap, and the trap was filled until toluene ran over into the flask. Heat was provided to the flask so the toluene would boil within 10 min, at which point the 90 -min reflux began. Moisture measurements 
were obtained at $30,45,60,75$, and $90 \mathrm{~min}$, and the condenser was rinsed with toluene at 45, 60, 75, and 90 min. An aliquot of the distilled liquid was collected via glass syringe. Two milliliters of this liquid plus $0.2 \mathrm{~mL}$ 2-ethylbutyrate solution $(0.365 \mathrm{~g}$ 2-ethylbutyrate in $100 \mathrm{~mL}$ double-distilled $\mathrm{H}_{2} \mathrm{O}$ ) was analyzed for volatiles using gas chromatography based on methodology described by Erwin et al. (1961). Specific organic compounds were not identified but were summed to equal total volatiles.

\section{Experiment 3}

A follow-up study on drying methods was conducted to evaluate DM content for 27 WDGS, 22 MDGS, and 14 wet grains with no solubles (WG; POET Nutrition) samples. Weekly subsamples of these by-products were collected from June 2006 through December 2008 when they were being fed at the University of NebraskaLincoln Agricultural Research and Development Center research feedlot near Mead, Nebraska. The samples were composited by as-is weight to make a monthly composite sample.

Dry matter was analyzed in duplicate with toluene distillation, $60^{\circ} \mathrm{C}$ oven drying for $48 \mathrm{~h}$, and $105^{\circ} \mathrm{C}$ oven drying for $3 \mathrm{~h}$. Toluene distillations were conducted as previously stated but were refluxed for 75 min because this was determined to be the maximum time needed to recover all potential moisture. The $60^{\circ} \mathrm{C}$ and $105^{\circ} \mathrm{C}$ oven DM methods were conducted with 20-g and 1-g as-is samples, respectively. If the sample $\mathrm{CV}$ was greater than $5 \%$ within each method, then the analysis was repeated.

To determine amount of volatiles lost by drying in the $60^{\circ} \mathrm{C}$ oven for 48 h, 3 WDGS, 1 MDGS, and 1 WG samples were analyzed by toluene distillation comparing the as-is samples to oven-dried samples that were reconstituted to their original moisture content with distilled $\mathrm{H}_{2} \mathrm{O}$. The amount of volatiles in the distilled liquid was analyzed using a gas chromatograph as previously stated.

Data were analyzed using the MIXED procedure of SAS for each experiment. Dry matter method and by-product type were considered fixed effects, and interactions between these were tested for significance $(P$ $<0.05)$. Simple effects are reported regardless of significant interactions to illustrate DM for each by-product type.

Table 1. CV\% ${ }^{1}$ for $\mathrm{DM}^{2}$ by ethanol plant and sampling period

\begin{tabular}{llllllll} 
& \multicolumn{7}{c}{ Ethanol plant } \\
\cline { 2 - 7 } Item & A & B & C & D & E & F & \multicolumn{1}{c}{ CV F-test $^{3}$} \\
\hline Period 1 & 1.27 & 3.23 & 2.42 & 1.99 & 1.07 & 2.03 & 0.14 \\
Period 2 & $0.88^{\mathrm{ab}}$ & $0.80^{\mathrm{a}}$ & $1.99^{\mathrm{ab}}$ & $3.09^{\mathrm{b}}$ & $0.89^{\mathrm{ab}}$ & $2.52^{\mathrm{b}}$ & $<0.01$ \\
Period 3 & $1.41^{\mathrm{a}}$ & $1.26^{\mathrm{a}}$ & $2.90^{\mathrm{b}}$ & $1.28^{\mathrm{a}}$ & $1.52^{\mathrm{a}}$ & $1.55^{\mathrm{a}}$ & $<0.01$ \\
Period 4 & $0.62^{\mathrm{a}}$ & $3.07^{\mathrm{b}}$ & $2.07^{\mathrm{ab}}$ & $1.62^{\mathrm{ab}}$ & $2.31^{\mathrm{ab}}$ & $1.61^{\mathrm{ab}}$ & 0.03 \\
Avg CV & 1.05 & 2.09 & 2.35 & 2.00 & 1.45 & 1.93 & \\
\hline
\end{tabular}

a,b Means in the same row without a common superscript differ $(P<0.05)$.

${ }^{1} \mathrm{CV}$ represents an average of the $\mathrm{CV}$ calculated within day for each day (5d) by each period.

${ }^{2} \mathrm{DM}$ was determined by drying samples in a $60^{\circ} \mathrm{C}$ oven for $48 \mathrm{~h}$.

${ }^{3} \mathrm{CV} F$-test represents the $\mathrm{F}$-test detected for ethanol plant differences in $\mathrm{CV}$ within each period.

${ }^{4} \mathrm{Avg}$ CV represents the average of the $20 \mathrm{CV}$ calculated within each of the 20 individual days of the 4 sampling periods.

\section{RESULTS AND DISCUSSION}

\section{Experiment 1}

Average DM for WDGS and MDGS were 32.5 and $45.2 \%$, respectively. For confidentiality, actual DM contents by plant are not disclosed. Therefore, DM values were converted to a $100 \%$ basis. Regardless of type of distillers grain, the DM content varied between plants (data not shown), which emphasizes the importance of producers knowing the DM of the product purchased. Coefficients of variation (independent of the mean) were different across ethanol plants and within sampling periods (50 samples per plant per period), but this variation remained relatively small, as only 3 values were above $4 \%(4.0,4.7$, and $7.1 \%$ ) for $24 \mathrm{CV}$ calculated. This variation is similar to the findings of Kaiser (2005), who reported CV of 2.8 to $3.8 \%$ within each plant for WDGS samples collected from 3 ethanol plants. Differences in mean DM by ethanol plant can be understood due to plant production systems. Holt and Pritchard (2004) observed greater DM variation for samples collected across ethanol plants, with CV of 6.8 and $4.7 \%$ for WDGS and MDGS, respectively. In the current experiment, variability in DM was also observed within day, and the $\mathrm{CV}$ were different by plant for periods 2,3 , and $4(P \leq$ 0.03 , Table 1). However, CV were less than or equal to $3.1 \%$, which are relatively small. The average CV across all $20 \mathrm{~d}$ of sampling within each ethanol plant ranged from 1.05 to $2.35 \%$. Across-day variation for DM was also small, with CV less than $3 \%$ within each ethanol plant (data not shown). Although DM content of by-products is very important, CV less than $5 \%$ may not be of practical significance. Some of this variation is likely attributable to sampling accuracy.

The concentration of CP for WDGS was $31.0 \%$ (DM basis) across all ethanol plants and sampling periods, which was greater than the $29.5 \%$ reported by NRC (1996). Mean CP by plant ranged from 30.1 to $32.2 \%$ $(P<0.01$, Table 2$)$, but CP within 
Table 2. Average ${ }^{1}$ and $\mathrm{CV} \%^{2}$ for $\mathrm{CP}$ by ethanol plant and sampling period

\begin{tabular}{|c|c|c|c|c|c|c|c|c|}
\hline \multirow[b]{2}{*}{ Item } & \multicolumn{6}{|c|}{ Ethanol plant } & \multirow{2}{*}{$\begin{array}{c}\text { CV } \\
\text { F-test } \\
\end{array}$} & \multirow{2}{*}{$\begin{array}{r}\text { Avg CP } \\
F \text {-test }^{4}\end{array}$} \\
\hline & A & B & C & D & $E$ & $\mathbf{F}$ & & \\
\hline Period 1 & $30.9\left(1.29^{a}\right)$ & $34.0\left(3.72^{c}\right)$ & $30.5\left(1.69^{a b}\right)$ & $30.3\left(2.46^{\mathrm{ab}}\right)$ & $30.7\left(1.45^{\mathrm{ab}}\right)$ & $29.6\left(2.72^{\mathrm{bc}}\right)$ & 0.01 & \\
\hline Period 2 & $30.8(1.24)$ & $30.9(1.24)$ & $30.4(1.34)$ & $30.2(1.68)$ & $32.4(1.15)$ & $31.0(1.25)$ & 0.15 & \\
\hline Period 3 & $31.2\left(0.96^{a}\right)$ & $31.9\left(0.92^{a}\right)$ & $30.8\left(1.38^{\mathrm{ab}}\right)$ & $30.6\left(0.99^{a}\right)$ & $30.8\left(1.79^{b}\right)$ & $29.4\left(1.57^{b}\right)$ & 0.01 & \\
\hline Period 4 & $31.5\left(0.93^{a}\right)$ & $32.0\left(2.06^{b}\right)$ & $32.0\left(1.12^{a}\right)^{\prime}$ & $31.4\left(1.00^{a}\right)$ & $30.9\left(1.25^{a}\right)$ & $30.4\left(1.00^{a}\right)$ & $<0.01$ & \\
\hline Avg mean and $\mathrm{CV}^{5}$ & $31.1^{\mathrm{c}}(1.11)$ & $32.2^{\mathrm{d}}(1.99)$ & $30.9^{\mathrm{bc}}(1.38)$ & $30.6^{b}(1.53)$ & $31.2^{\mathrm{c}}(1.41)$ & $30.1^{a}(1.64)$ & & $<0.01$ \\
\hline
\end{tabular}

a-dMeans in the same row without a common superscript differ $(P<0.05)$.

${ }^{1}$ Average represents each ethanol plant's average for the 50 samples (10 samples/d for $5 \mathrm{~d}$ ) collected within each period. Averages represented as a percentage of DM.

${ }^{2} \mathrm{CV}$ (presented in parentheses) represents an average of the CV calculated within day for each day ( $5 \mathrm{~d}$ ) by each period.

${ }^{3} \mathrm{CV} F$-test represents the $F$-test detected for ethanol plant differences in $\mathrm{CV}$ within each period.

${ }^{4} \mathrm{Avg}$ CP F-test represents the $F$-test detected for ethanol plant differences in average CP.

${ }^{5} \mathrm{Avg}$ mean and CV represents the average mean over the 4 sampling periods and the average of the $20 \mathrm{CV}$ calculated within each of the 20 individual days of the 4 sampling periods.

plant and by period only differed by 2 percentage units of the plant's overall mean. This range in $\mathrm{CP}$ content observed among plants was similar to the ranges reported by Spiehs et al. (2002) and Akayezu et al. (1998) of 28.7 to $31.6 \%$ and 27.7 to $32.3 \%$, respectively, for dry distillers grains with solubles (DDGS). In the current experiment, CP contents were different $(P<0.01)$ by ethanol plant, which can be expected due to production differences. However, variation within sampling period for each ethanol plant remained small, with CV less than 3\% (except for one value at $3.9 \%$; data not shown). Although the within-day variation $\mathrm{CV}$ were different by ethanol plant for periods 1,3 , and $4(P \leq 0.01)$, these values were generally less than $2.7 \%$ (only one value at $3.72 \%$ ). These resulted in SD of 0.3 to 1.3. When calculating the average of $\mathrm{CV}$ obtained within each of the $20 \mathrm{~d}$ of the 4 periods of sampling, these values were less than $2 \%$, suggesting little within-day variation across sampling periods. Across-day variation within plant was small as well, with CV below 1.6\% (data not shown). The SD observed for $\mathrm{CP}$ within plant and period were slightly less than the 1.4 observed by Holt and Pritchard (2004) and the 1.5 to 1.6 observed by Kaiser
(2005). Soybean meal is considered a consistent feedstuff. However, the NRC (1996) reported a CP average of $51.8 \%$ for soybean meal with a SD of 3.45 for 786 samples tested. We did not consider the SD reported in this experiment for WDGS highly variable because they were less than the SD observed for soybean meal.

The average fat content for all of the samples was $11.9 \%$ (DM basis), which was greater than the $10.3 \%$ reported by the NRC (1996). Although the mean fat content by ethanol plant and averaged across periods ranged from 10.9 to $13.0 \%$ (Table 3), the variation appeared to be largely dependent on the ethanol plant and not the sampling periods because plant means were different from each other $(P<0.01)$. Spiehs et al. $(2002)$ and Akayezu et al. (1998) reported fat ranges for DDGS within ethanol plants of 10.2 to $11.7 \%$ and 8.8 to $12.4 \%$, respectively. Holt and Pritchard (2004) also showed differences in fat content in WDGS and DDGS among ethanol plants, ranging from 10.4 to $14.2 \%$. These data suggest there are processing differences from plant to plant that influence fat levels (which may relate to the amount of distillers solubles that are added to the distillers grain). The within-day CV for fat were generally less than
$5 \%$ (only one value was greater, $6.6 \%)$. Across-day variation was similar to within-day variation; CV were 1.2 to $4.5 \%$ within plant (data not shown). On a practical level, because the mean fat concentration among plants differed more than the CV associated within each plant's mean, producers should monitor the average fat content of WDGS from their ethanol plant and be less concerned with load-to-load variation in fat. Dietary fat content is important information because DMI can decrease when dietary fat is greater than $8 \%$ (Vander Pol et al., 2009).

The average $\mathrm{P}$ content for all of the samples was $0.84 \%$ (DM basis), and $\mathrm{P}$ content was different among plants, with a range of 0.78 to $0.91 \%$ $(P<0.01$, Table 4$)$. The NRC $(1996)$ reported $0.32 \% \mathrm{P}$ for WDGS, and Holt and Pritchard (2004) observed a range of 0.49 to $0.78 \% \mathrm{P}$ for WDGS and DDGS. However, Spiehs et al. (2002) reported an average of $0.89 \%$ $\mathrm{P}$ for DDGS, and Kaiser (2005) reported averages of 0.8 to $0.9 \% \mathrm{P}$ within ethanol plants. In the current study, minimal within-day variation was observed for $\mathrm{P}$, and the $\mathrm{CV}$ were 1.1 to $3.4 \%$, resulting in SD of 0.01 to 0.03 . This measure of within-day variation was only different $(P<0.01)$ for period 2 , suggesting consistent 
Table 3. Average ${ }^{1}$ and $\mathrm{CV} \%^{2}$ for fat by ethanol plant and sampling period

\begin{tabular}{|c|c|c|c|c|c|c|c|c|}
\hline \multirow[b]{2}{*}{ Item } & \multicolumn{6}{|c|}{ Ethanol plant } & \multirow{2}{*}{$\begin{array}{c}\text { CV } \\
F \text {-test }\end{array}$} & \multirow{2}{*}{$\begin{array}{c}\text { Avg fat } \\
F \text {-test }{ }^{4}\end{array}$} \\
\hline & A & B & C & D & $E$ & $\mathbf{F}$ & & \\
\hline Period 1 & $12.5\left(2.31^{\mathrm{a}}\right)$ & $10.8\left(6.55^{c}\right)$ & $12.7\left(3.03^{\mathrm{ab}}\right)$ & $12.4\left(3.66^{\mathrm{ab}}\right)$ & $11.5\left(2.80^{\mathrm{ab}}\right)$ & $11.5\left(4.99^{b c}\right)$ & 0.01 & \\
\hline Period 2 & $11.7\left(1.76^{a}\right)$ & $10.7\left(2.03^{a}\right)$ & $13.1\left(3.52^{\mathrm{abc}}\right)$ & $11.7\left(2.80^{\mathrm{ab}}\right)$ & $11.8\left(5.70^{c}\right)^{\prime}$ & $11.7\left(4.49^{\mathrm{bc}}\right)$ & 0.02 & \\
\hline Period 3 & $12.1(1.32)$ & $11.3(2.39)^{\prime}$ & $13.3(2.59)$ & $12.4(2.02)$ & $10.2(2.23)^{\prime}$ & $12.4(1.96)$ & 0.38 & \\
\hline Period 4 & $11.9\left(1.64^{a}\right)$ & $11.3\left(2.83^{b}\right)$ & $13.0\left(2.25^{\mathrm{ab}}\right)$ & $12.3\left(1.99^{a b}\right)$ & $10.3\left(2.74^{b}\right)$ & $12.4\left(1.52^{a}\right)$ & 0.03 & \\
\hline Avg mean and $\mathrm{CV}^{5}$ & $12.1^{\mathrm{b}}(1.76)$ & $11.0^{\mathrm{a}}(3.45)$ & $13.0^{\circ}(2.85)^{\prime}$ & $12.2^{\mathrm{b}}(2.62)^{\prime}$ & $10.9^{\mathrm{a}}(3.37)$ & $12.0^{\mathrm{b}}(3.24)$ & & $<0.01$ \\
\hline
\end{tabular}

${ }^{\mathrm{a}-\mathrm{c} M e a n s}$ in the same row without a common superscript differ $(P<0.05)$.

${ }^{1}$ Average (\% of DM) represents each ethanol plant's average for the 50 samples (10 samples/d for $5 \mathrm{~d}$ ) collected within each period.

${ }^{2} \mathrm{CV}$ (presented in parentheses) represents an average of the CV calculated within day for each day (5 d) by each period.

${ }^{3} \mathrm{CV} F$-test represents the $F$-test detected for ethanol plant differences in $\mathrm{CV}$ within each period.

${ }^{4} \mathrm{Avg}$ fat $F$-test represents the $F$-test detected for ethanol plant differences in average fat.

${ }^{5} \mathrm{Avg}$ mean and CV represents the average mean over the 4 sampling periods and the average of the $20 \mathrm{CV}$ calculated within each of the 20 individual days of the 4 sampling periods.

within-day $\mathrm{P}$ variation among plants. Across-day variation was small for $\mathrm{P}$, and $\mathrm{CV}$ by ethanol plant were 1.2 to $2.8 \%$ (data not shown). Kaiser (2005) reported $\mathrm{SD}$ for $\mathrm{P}$ of 0.1 to 0.2 for WDGS. The NRC (1996) reported an average of $0.73 \% \mathrm{P}$ with a SD of 0.20 for 352 soybean meal samples and a $0.07 \% \mathrm{P}$ average with a SD of 0.25 for 3,516 corn grain samples analyzed. The SD of $\mathrm{P}$ in WDGS in the current experiment was much less, suggesting $\mathrm{P}$ variability was small compared with soybean meal and corn. No toxicity for $\mathrm{P}$ is likely in ruminants at dietary concentrations up to $1 \%$, so $\mathrm{P}$ content of WDGS is not an issue for the animal. However, the amount of $\mathrm{P}$ is important information when balancing diets for $\mathrm{Ca}$ and to prevent urinary calculi (NRC, 1996). It is also important to know the $\mathrm{P}$ content of WDGS to accurately assess total diet $\mathrm{P}$ for nutrient management plans and when spreading manure on crop fields.

Average $\mathrm{S}$ content for all of the samples was $0.77 \%$ (DM basis), which is greater than the $0.40 \%$ reported by the NRC (1996). Sulfur values were numerically greater in period
1 than in the other 3 periods (Table $5)$. One of the plants in period 1 had an average $\mathrm{S}$ content of $1.06 \%$, with a range of 0.90 to $1.26 \%$ and $\mathrm{CV}$ of $6.17 \%$ within day. Another plant in period 1 had an average $S$ content of $0.71 \%$, but the $\mathrm{CV}$ was $36.3 \%$ ( 0.26 $\mathrm{SD})$ due to a range of 0.44 to $1.72 \%$ $\mathrm{S}$ for individual samples. After period 1 sampling, results were presented to managers of the ethanol plants. We observed lower S means and CV for plants in subsequent periods. Specifically, means by plant for all samples ranged from 0.71 to $0.84 \%$

\section{Table 4. Average ${ }^{1}$ and $\mathrm{CV} \%^{2}$ for $\mathrm{P}$ by ethanol plant and sampling period}

\begin{tabular}{|c|c|c|c|c|c|c|c|c|}
\hline \multirow[b]{2}{*}{ Item } & \multicolumn{6}{|c|}{ Ethanol plant } & \multirow{2}{*}{$\begin{array}{c}\text { CV } \\
F \text {-test }^{3}\end{array}$} & \multirow{2}{*}{$\begin{array}{l}\text { Avg P } \\
\text { F-test }\end{array}$} \\
\hline & A & B & C & D & E & $\mathbf{F}$ & & \\
\hline Period 1 & $0.83(2.11)$ & 0.79 (3.39) & 0.87 (2.23) & $0.85(2.34)$ & $0.80(2.11)$ & $0.78(2.55)$ & 0.53 & \\
\hline Period 2 & $0.84\left(1.49^{a b}\right)$ & $0.76\left(1.37^{\mathrm{ab}}\right)$ & $0.90\left(2.85^{c}\right)$ & $0.87\left(2.47^{\mathrm{bc}}\right)$ & $0.80\left(1.07^{a}\right)$ & $0.80\left(3.13^{c}\right)$ & $<0.01$ & \\
\hline Period 3 & $0.84(1.25)$ & $0.78(1.77)$ & $0.92(2.76)$ & $0.87(1.54)$ & $0.74(1.79)$ & $0.86(1.46)$ & 0.14 & \\
\hline Period 4 & $0.86(1.36)$ & $0.79(2.39)$ & $0.93(2.13)$ & $0.89(1.63)$ & $0.80(2.73)$ & $0.86(1.28)$ & 0.15 & \\
\hline Avg mean and $\mathrm{CV}^{5}$ & $0.84^{c}(1.55)$ & $0.78^{a}(2.23)$ & $0.91^{\mathrm{e}}(2.49)$ & $0.87^{d}(2.00)$ & $0.78^{a}(1.93)$ & $0.82^{\mathrm{b}}(2.11)$ & & $<0.01$ \\
\hline
\end{tabular}

${ }^{a-e}$ Means in the same row without a common superscript differ $(P<0.05)$.

${ }^{1}$ Average (\% of DM) represents each ethanol plant's average for the 50 samples (10 samples/d for $5 \mathrm{~d}$ ) collected within each period. ${ }^{2} \mathrm{CV}$ (presented in parentheses) represents an average of the CV calculated within day for each day (5 d) by each period.

${ }^{3} \mathrm{CV} F$-test represents the F-test detected for ethanol plant differences in $\mathrm{CV}$ within each period.

${ }^{4} \mathrm{Avg} P \mathrm{~F}$-test represents the $F$-test detected for ethanol plant differences in average $\mathrm{P}$.

${ }^{5} \mathrm{Avg}$ mean and CV represents the average mean over the 4 sampling periods and the average of the $20 \mathrm{CV}$ calculated within each of the 20 individual days of the 4 sampling periods. 
Table 5. Average ${ }^{1}$ and $\mathrm{CV} \%^{2}$ for $\mathrm{S}$ by ethanol plant and sampling period

\begin{tabular}{|c|c|c|c|c|c|c|c|c|}
\hline \multirow[b]{2}{*}{ Item } & \multicolumn{6}{|c|}{ Ethanol plant } & \multirow{2}{*}{$\begin{array}{c}\text { CV } \\
F \text {-test }^{3}\end{array}$} & \multirow{2}{*}{$\begin{array}{l}\text { Avg S } \\
F \text {-test }\end{array}$} \\
\hline & A & B & C & D & $E$ & $\mathbf{F}$ & & \\
\hline Period 1 & 0.71 (12.88) & $0.72(5.60)$ & 0.83 (5.53) & $1.06(6.17)$ & $0.81(5.20)$ & $0.90(5.50)$ & 0.13 & \\
\hline Period 2 & $0.76\left(7.21^{b}\right)$ & $0.74\left(4.06^{a}\right)$ & $0.72\left(4.82^{\mathrm{ab}}\right)$ & $0.69\left(3.25^{\mathrm{a}}\right)$ & $0.76\left(3.29^{a}\right)$ & $0.82\left(3.69^{a}\right)$ & 0.02 & \\
\hline Period 3 & $0.67\left(4.95^{\mathrm{bc}}\right)$ & $0.75\left(3.11^{\mathrm{a}}\right)$ & $0.73\left(6.38^{c}\right)$ & $0.78\left(3.81^{a b}\right)$ & $0.75\left(3.97^{\mathrm{ab}}\right)$ & $0.89\left(2.96^{a}\right)$ & 0.01 & \\
\hline Period 4 & $0.69(3.49)$ & $0.73(3.15)$ & $0.76(3.98)$ & $0.76(4.82)$ & $0.72(3.50)$ & $0.77(3.50)$ & 0.44 & \\
\hline Avg mean and $\mathrm{CV}^{5}$ & $0.71^{a}(7.13)$ & $0.74^{\mathrm{ab}}(3.98)$ & $0.76^{\mathrm{ab}}(5.18)$ & $0.82^{\mathrm{c}}(4.51)$ & $0.76^{\mathrm{b}}(3.99)$ & $0.84^{\mathrm{c}}(3.91)$ & & $<0.01$ \\
\hline
\end{tabular}

a-cMeans in the same row without a common superscript differ $(P<0.05)$.

${ }^{1}$ Average (\% of DM) represents each ethanol plant's average for the 50 samples (10 samples/d for $5 \mathrm{~d}$ ) collected within each period.

${ }^{2} \mathrm{CV}$ (presented in parentheses) represents an average of the CV calculated within day for each day (5 d) by each period.

${ }^{3} \mathrm{CV} F$-test represents the $F$-test detected for ethanol plant differences in $\mathrm{CV}$ within each period.

${ }^{4} \mathrm{Avg} S \mathrm{~F}$-test represents the $\mathrm{F}$-test detected for ethanol plant differences in average $\mathrm{S}$.

${ }^{5} \mathrm{Avg}$ mean and CV represents the average mean over the 4 sampling periods and the average of the $20 \mathrm{CV}$ calculated within each of the 20 individual days of the 4 sampling periods.

$(P<0.01)$, and $\mathrm{CV}$ by plant and within periods 2,3 , and 4 were 2.2 to $12.8 \%$, resulting in SD equal to or less than 0.10 (data not shown). Spiehs et al. (2002) reported a range for $\mathrm{S}$ means with 12 ethanol plants of 0.33 to $0.74 \%$ and CV ranging from 6.4 to $40.8 \%$. Variation within day for $\mathrm{S}$ appeared to be greater than any other nutrient and generally resulted in $\mathrm{CV}$ less than $6.2 \%$ (one value at $12.9 \%$ ) and were different $(P \leq 0.02)$ among plants for periods 2 and 3 . Across-day variation within plant was numerically similar to within-day variation, and CV were 1.9 to $7.7 \%$, with one value at $13.3 \%$ (data not shown). Holt and Pritchard (2004) reported high variability in $\mathrm{S}$ levels for DDGS, but the variability was not quantified. These data suggest $\mathrm{S}$ values should be routinely monitored because increases in S of WDGS can lead to nutritional challenges for cattle (NRC, 1996), especially when feeding more than $30 \%$ of diet DM.

Table 6. Average percent DM of 4 different ethanol by-products ${ }^{1}$ evaluated by different methods ${ }^{2}$

\begin{tabular}{|c|c|c|c|c|c|c|c|c|}
\hline \multirow[b]{2}{*}{ Sample } & \multicolumn{2}{|c|}{$60^{\circ} \mathrm{C}$} & \multicolumn{3}{|c|}{$105^{\circ} \mathrm{C}$} & \multirow[b]{2}{*}{ Toluene } & \multirow[b]{2}{*}{ Vacuum } & \multirow[b]{2}{*}{$F$-test } \\
\hline & $24 \mathrm{~h}$ & $48 \mathrm{~h}$ & $3 \mathrm{~h}$ & $8 \mathrm{~h}$ & $24 \mathrm{~h}$ & & & \\
\hline WDGS & $33.2^{\mathrm{d}}$ & $33.0^{\mathrm{cd}}$ & $32.7^{c}$ & $32.2^{b}$ & $31.6^{a}$ & $33.2^{d}$ & $35.2^{\mathrm{e}}$ & $<0.01$ \\
\hline MDGS & $44.1^{f}$ & $43.7^{e}$ & $42.9^{c}$ & $42.2^{b}$ & $41.3^{a}$ & $43.3^{d}$ & $45.0^{g}$ & $<0.01$ \\
\hline Dbran & $54.0^{e}$ & $53.7^{d}$ & $52.8^{c}$ & $52.1^{b}$ & $51.3^{a}$ & $53.7^{d}$ & $55.4^{f}$ & $<0.01$ \\
\hline DS & $35.6^{\text {de }}$ & $34.9^{d}$ & $33.5^{c}$ & $32.2^{b}$ & $31.1^{\mathrm{a}}$ & $35.9^{\mathrm{de}}$ & $35.8^{e}$ & $<0.01$ \\
\hline
\end{tabular}

a-gMeans within the same row with different superscripts differ $(P \leq 0.10)$.

${ }^{1}$ WDGS = wet distillers grains plus solubles; MDGS = modified wet distillers grains plus solubles; Dbran = Dakota Bran Cake (POET Nutrition, Sioux Falls, SD); DS = distillers solubles. Analysis included 8 replicates for oven drying methods and toluene distillation and 3 replicates for vacuum drying per sample.

${ }^{2}$ Methods: $60^{\circ} \mathrm{C}=$ oven drying at $60^{\circ} \mathrm{C}$ for 24 or $48 \mathrm{~h} ; 105^{\circ} \mathrm{C}=$ oven drying at $105^{\circ} \mathrm{C}$ for 3,8 , or $24 \mathrm{~h}$; Toluene = toluene distillation; Vacuum = vacuum oven drying. No interactions resulted between drying method and by-product type $(P \geq 0.58)$. Drying method differed within by-product type $(P<0.01)$.

\section{Experiment 2}

No interactions of type of byproduct and time dried at temperatures of $105^{\circ} \mathrm{C}$ or $60^{\circ} \mathrm{C}(P=0.58)$ were observed for DM content. All samples dried in the $105^{\circ} \mathrm{C}$ oven linearly decreased $(P<0.01)$ in $\mathrm{DM}$ over time, and average DM content was $40.5,39.7$, and $38.8 \%$ at 3,8 , and $24 \mathrm{~h}$, respectively. A lower $(P=$ $0.06) \mathrm{DM}$ content was obtained for samples dried in a $60^{\circ} \mathrm{C}$ oven for $48 \mathrm{~h}$ (41.3\%) compared with 24 h $(41.7 \%$, Table 6). A greater $(P<0.01) \mathrm{DM}$ content was observed when a vacuum oven was used for WDGS (35.2\%) and MDGS (45.0\%) compared with all other methods. Vacuum drying also resulted in greater DM $(54.4 \%$; $P<0.01)$ for Dbran compared with toluene distillation $(53.7 \%)$ or oven drying at $60^{\circ} \mathrm{C}(54.0$ and $53.7 \%$ for 24 and $48 \mathrm{~h}$, respectively). No differences were observed for DS between toluene distillation and vacuum drying $(P=$ $0.74)$. This suggests the vacuum oven removes more apparent moisture with some samples than others.

The DM determined from toluene distillation was $33.2,43.3,53.7$, and $35.9 \%$ for WDGS, MDGS, Dbran, and DS, respectively. There were no differences in DM for WDGS $(P \geq$ $0.36)$ and Dbran $(P \geq 0.18)$ between methods of toluene distillation and 


\section{Table 7. Average percent DM of 3 different ethanol by-products ${ }^{1}$ evaluated by different methods ${ }^{2}$}

\begin{tabular}{|c|c|c|c|c|}
\hline Sample & $60^{\circ} \mathrm{C}, 48 \mathrm{~h}$ & $105^{\circ} \mathrm{C}, 3 \mathrm{~h}$ & Toluene & $F$-test \\
\hline WDGS & $33.3^{b}$ & $32.6^{a}$ & $33.5^{b}$ & 0.01 \\
\hline MDGS & 49.7 & 49.0 & 49.5 & 0.60 \\
\hline WG & 32.6 & 32.3 & 32.2 & 0.88 \\
\hline
\end{tabular}

a,b Means within the same row with different superscripts differ $(P \leq 0.10)$.

${ }^{1}$ WDGS = wet distillers grains plus solubles; MWDGS = modified wet distillers grains plus solubles; $W G=$ wet distillers grains with no solubles. Analysis included 27 samples for WDGS, 22 for MDGS, and 14 for WG.

2Methods: $60^{\circ} \mathrm{C}, 48 \mathrm{~h}=$ oven drying at $60^{\circ} \mathrm{C}$ for $48 \mathrm{~h} ; 105^{\circ} \mathrm{C}, 3 \mathrm{~h}=$ oven drying at $105^{\circ} \mathrm{C}$ for $3 \mathrm{~h}$; Toluene $=$ toluene distillation. No interaction resulted for drying method and by-product sample on percent DM $(P=0.84)$.

oven drying at $60^{\circ} \mathrm{C}$ for 24 or $48 \mathrm{~h}$, and DM was also not different $(P=$ 0.21 ) for DS using toluene distillation and the $60^{\circ} \mathrm{C}$ oven for $24 \mathrm{~h}$. In many commercial laboratories, drying in a $105^{\circ} \mathrm{C}$ oven for $3 \mathrm{~h}$ is the preferred method for determining DM because results can be obtained within the same day. However, in this experiment, we observed that oven drying at $105^{\circ} \mathrm{C}$ for $3 \mathrm{~h}$ or longer resulted in a lower $(P \leq 0.10)$ DM content compared with that determined by toluene distillation or oven drying at $60^{\circ} \mathrm{C}$ for $48 \mathrm{~h}$. This effect was observed for all 4 by-product types and suggests that volatile compounds are lost in addition to water. Thiex and Van Erem (1999) also discovered that drying samples in ovens at greater temperatures, $135^{\circ} \mathrm{C}$ compared with $104^{\circ} \mathrm{C}$, underestimated DM content (underestimates DM) for haylage and corn silage samples.

Dry matter results from the Karl Fischer analysis were 37.3, 45.6, 54.8, and $35.7 \%$ for WDGS, MDGS, Dbran, and DS, respectively, but no statistical comparisons to other methods were conducted because only 2 replicates were used with this procedure. However, DM estimates obtained from the Karl Fischer method were numerically greater for WDGS and MDGS than for all other methods and were greater for Dbran and DS compared with oven drying. This discrepancy may be because the accuracy of the Karl Fischer method depends on the accuracy of the calibration standard (Thiex and Van Erem, 2002). In addition, Thiex and Van Erem (1999) reported higher correlation coefficients and slope (closer to 1) for dry hay than for haylage and corn silage when comparing methods of oven drying at 104 or $135^{\circ} \mathrm{C}$ to Karl Fischer, suggesting poor DM comparisons between oven drying and Karl Fischer titration with wetter feeds $(<70 \% \mathrm{DM})$. The American Feed Industry Association (2007) did not recommend the Karl Fischer moisture test for determining DM for dry distillers grains plus solubles but instead recommended drying the samples in a $105^{\circ} \mathrm{C}$ oven for $3 \mathrm{~h}$. They stated using this oven method resulted in small biased DM contents with acceptable CV and a small economic risk with minimal labor costs.

\section{Experiment 3}

No significant interactions were observed for DM between drying method and by-product sample type $(P=0.84)$. Type of sample had a significant effect $(P<0.01)$ on DM content, but drying method of toluene distillation and oven drying were not different $(P=0.20)$. However, DM estimates determined from toluene distillation (38.4\%) were numerically closer to the values obtained from drying samples in a $60^{\circ} \mathrm{C}$ oven for 48 h $(38.5 \%)$ compared with DM values observed from drying samples at $105^{\circ} \mathrm{C}$ for $3 \mathrm{~h}(38.0 \%$, Table 7$)$. These results are similar to those observed in Exp. 2, in which oven drying at $60^{\circ} \mathrm{C}$ for $48 \mathrm{~h}$ resulted in closer numeric values to toluene distillation than did oven drying at $105^{\circ} \mathrm{C}$ for $3 \mathrm{~h}$.

When the toluene distillation procedure was performed and the liquid was collected for volatiles analysis in a gas chromatograph, acetic acid was detected at the same time as residual toluene. Therefore, the contamination of toluene with volatiles was evaluated by conducting toluene distillation and determining the amount of toluene in the gas chromatograph collected in the water with moistened corn bran (30\% DM) that contained no volatiles. The amount of toluene was very small $(0.08 \%$ of DM), which suggests a large proportion of this peak was acetic acid.

The original by-product samples contained $0.74 \%$ volatiles (of DM), and the reconstituted samples contained $0.17 \%$ volatiles (of DM) after oven drying at $60^{\circ} \mathrm{C}$ for $48 \mathrm{~h}$. This suggests that a large proportion of the volatiles contained in wet by-products are lost in oven drying processes, which results in underestimation of DM content. However, drying wet by-products at $60^{\circ} \mathrm{C}$ for $48 \mathrm{~h}$ resulted in the DM content most similar to toluene distillation. Therefore, this suggests that drying wet by-products at $60^{\circ} \mathrm{C}$ for $48 \mathrm{~h}$ causes some volatiles to be lost. However, it is likely that samples are also not completely dry. The net result is that oven drying at $60^{\circ} \mathrm{C}$ for $48 \mathrm{~h}$ is similar to toluene distillation.

Drying wet samples at $60^{\circ} \mathrm{C}$ for 48 $\mathrm{h}$ to determine DM content may be an inexpensive and safe method for obtaining accurate estimates of DM for wet corn milling by-products. Determining DM analysis using $105^{\circ} \mathrm{C}$ for $3 \mathrm{~h}$ gave average values that were 0.79 percentage units $(2 \%)$ lower than those from toluene distillation. Nutritionists and producers should be aware of and account for this discrepancy if this method is used by their commercial laboratories. Values for DM determined in $60^{\circ} \mathrm{C}$ ovens for 48 
$\mathrm{h}$ were within 0.06 percentage units of those from toluene distillation.

\section{IMPLICATIONS}

Nutrient composition of WDGS samples was as follows: $31.0 \% \mathrm{CP}$, $11.9 \%$ fat, $0.84 \%$ P, and $0.77 \%$ S. Dry matter content should be known and periodically checked because this is important when purchasing wet feed. Fat content should be determined if a producer changes source of WDGS, because greater differences were observed across plants than within the same plant. Sulfur content should also be routinely monitored, because significant variation was observed within the same day and across days of collection. Compared with toluene distillation, drying in a $105^{\circ} \mathrm{C}$ oven underestimated DM content for wet by-products, whereas the vacuum oven and the Karl Fischer titration overestimated DM content. Drying in a $60^{\circ} \mathrm{C}$ oven for $48 \mathrm{~h}$ was similar to toluene distillation and is the recommended method to obtain accurate $\mathrm{DM}$ values.

\section{LITERATURE CITED}

Akayezu, J. M., J. G. Linn, S. R. Harty, and J. M. Cassady. 1998. Use of distillers grains and co-products in ruminant diets. p. 1 in 59th Minnesota Nutr. Conf., Bloomington, $\mathrm{MN}$.

American Feed Industry Association. 2007. Evaluation of analytical methods for analysis of dried distillers grains with solubles. AFIA sub-working group final report and recommendations. Accessed March 11, 2010. http://www.afia.org/Afia/Files/BAMN-\%20 BSE-\%20DDGS-\%20Biosecurity\%20Awareness/DDGS\%20FINAL\%20Report\%20 and\%20Recommendations2-07.pdf.

AOAC. 1999. Official Methods of Analysis. 16th ed. AOAC, Arlington, VA.

AOCS. 1998. Official Methods and Recommended Practices of the AOCS. 5th ed. Am. Oil Chem. Soc., Champaign, IL.

Babcock, B. A., D. J. Hayes, and J. D.

Lawrence. 2008. Using Distillers Grains in the U.S. and International Livestock and Poultry Industries. Midwest Agribusiness Trade Research and Information Center, Iowa State University, Ames, IA.

Brahmakshatriya, R. D., and J. D. Donker. 1971. Five methods for determination of silage dry matter. J. Dairy Sci. 54:1470.

Erwin, E. S., G. J. Marco, and E. M. Emery. 1961. Volatile fatty acid analyses of blood and rumen fluid by gas chromatography. J. Dairy Sci. 44:1768.

Holt, S. M. and R. H. Pritchard. 2004. Composition and nutritive value of corn co-prod- ucts from dry milling ethanol plants. South Dakota Beef Rep. 2004-01:1-7.

Kaiser, R. M. 2005. Variation in composition of distillers wet grains with solubles. p. 191 in 4-State Dairy Nutr. Manage. Conf., Midwest Plan Service, Ames, IA.

Mo, M., and T. Tjornhom. 1978. Losses of carbon-containing substances during dry matter determination by oven drying. Acta Agric. Scand. 18:196.

NRC. 1996. Nutrient Requirements of Beef Cattle. Natl. Acad. Press, Washington, DC.

Spiehs, M. J., M. H. Whitney, and G. C. Shurson. 2002. Nutrient database for distillers dried grains with solubles produced from new ethanol plants in Minnesota and South Dakota. J. Anim. Sci. 80:2639.

Thiex, N., and T. Van Erem. 1999. Comparisons of Karl Fischer method with oven methods for determination of water in forages and animal feeds. J. AOAC 82:799.

Thiex, N., and T. Van Erem. 2002. Determination of water (moisture) and dry matter in animal feed, grain and forage (plant tissue) by Karl Fischer titration: Collaborative study. J. AOAC Int. 85:318.

Tinsdale, S. L., W. L. Nelson, and J. D. Beaton. 1985. Soil Fertility and Fertilizers. 4th ed. Macmillan Publ. Co., New York, NY.

Vander Pol, K. J., M. K. Luebbe, G. I. Crawford, G. E. Erickson, and T. J. Klopfenstein. 2009. Performance and digestibility characteristics of finishing diets containing distillers grains, composites of corn processing coproducts, or supplemental corn oil. J. Anim. Sci. 87:639. 